\title{
Work in Progress: Promoting Group Work for Learning: Student Charac- terizations of Exemplary Project Group Members
}

\section{Dr. Jim L. Borgford-Parnell, University of Washington}

Dr. Jim Borgford-Parnell is Director and Instructional Consultant of the Office for the Advancement of Engineering Teaching \& Learning at the University of Washington. He taught design, education-research methods, and adult and higher education theory and pedagogy courses for over 35 years. He has been involved in instructional development for 20 years, and currently does both research and instructional development in engineering education. Jim has taught courses on the development of reflective teaching practices, and has presented workshops on learning how to learn and developing metacognitive awareness. He has published and presented on engineering design, engineering pedagogies, and instructional development topics.

\section{Dr. Ken Yasuhara, University of Washington}

Ken Yasuhara is an instructional consultant and assistant director at the Office for the Advancement of Engineering Teaching \& Learning (ET\&L) at the University of Washington. He completed an A.B. in computer science at Dartmouth College and a Ph.D. in computer science and engineering at the University of Washington. When he finds the time, he plays with bicycle tools and knitting needles.

\section{Kamal Abdulla Ahmed, University of Washington \\ David Schipf, University of Washington}

David is currently a Ph.D. Candidate in Mechanical Engineering at the University of Washington in Seattle, WA. He is focusing on optical communications and other applied optics topics, as well as sensors and micro-systems. He has become increasingly interested in engineering education research and practical improvements to undergraduate and graduate education in the science and engineering fields. 


\section{WIP: Promoting group work for learning: Student characterizations of exemplary project group members}

\section{Introduction}

This Work-in-Progress paper details our extensive experience with a student workshop model and ongoing analysis of data collected in the workshops. At the University of Washington's Office for the Advancement of Engineering Teaching \& Learning, our primary activity is instructional consultation with faculty, but we also frequently guest-present a workshop for engineering students entitled "Teamwork for learning and project success."

The workshop's immediate, practical objective is to help students begin group work on the right footing. The fundamental emphasis, however, is on seeing group projects (at least in school) primarily as a context and vehicle for learning. Our experience suggests that both students and faculty tend to see efficient project completion, quality of work, and realistic preparation for professional life as the primary reasons for doing course projects in groups. While valid, none of these reasons alludes to the fact that learning with other people is a highly effective way to learn. Our workshop equips and encourages students and faculty alike to appreciate group project work in terms of knowledge retention and transfer. As with many of our guest workshops, we insist that faculty observe, so that they can also learn and, ideally, become comfortable with independently facilitating similar activities without our help. In this sense, we are not just facilitating workshops for students but also modeling facilitation for faculty.

The workshop is timed to occur after project groups have been formed. During the workshop, students confer in their project groups, and each group develops a consensus list of characteristics of exemplary and terrible group members. These characteristics become the criteria they later use for peer assessment.

Over the course of many workshops in several years, we have collected these lists from hundreds of groups and have begun analyzing them for common patterns. We discuss encouraging results suggesting that even lower-division undergraduates list characteristics that align well with the conditions that the group learning and project management literatures identify as contributing to successful learning and project completion, respectively.

We conjecture that much of the workshop's value lies in two distinct outcomes: (1) helping students articulate and place confidence in their experientially derived knowledge concerning effective group work and (2) helping both students and faculty (re-)frame the group project as a uniquely powerful opportunity for learning — not just a means toward successful project completion. Successful project completion is secondary and is at best a rough proxy measure of learning.

\section{Workshop Context}

We often ask engineering students at the beginning of our workshops, "Why do you think small groups are used so extensively in engineering courses?" The intent of the question and the ensuing discussion is to spark reflective examination of some of the assumptions students hold regarding this common engineering education experience. Usually a student answers with: 
"Because more people means more ideas for solving a problem or designing something," or possibly a student will say "When students work together they can divide up the work and get it done faster," or they may answer with, "Because engineers often work in teams, we need to learn teamwork skills." Each of those answers is correct and we expect each of the answers, because we know that students hear similar things from their professors. However, the answer we hope to hear but never expect to hear is, "Because learning with other people is a highly effective way to learn." This is a conception of group work we hope to promote with our workshops.

Over the last six years, engineering faculty members who teach courses in multiple engineering programs and at a variety of academic levels have asked us to facilitate our group work workshops for their students. The intent of the workshops is to help students in project-based and capstone design courses to start off their group work on solid footing.

We show students what learning effectively looks like (we call it the learning-well cycle) which involves successfully retaining knowledge and the ability to transfer that knowledge to a new context. We emphasize that successful knowledge transfer involves being able to access their own knowledge in situations wherein their knowledge would be helpful. We contrast this learning-well cycle with a learning cycle with which all students are at least implicitly familiarlearning something well-enough to pass an exam or a course, then forgetting much of what was learned, and then relearning it at a later date if necessary. The learning-well cycle has two primary components (retention, transfer) but we highlight access, which is a sub-component of transfer, because that is where the action is and that is where they can learn to take advantage of the cycle. In other words, it is at the access points in the cycle where being more metacognitive [1] and self-regulating [2] of their learning pays dividends.

We emphasize the access points in the cycle, because those points are where a learner might recall and use prior knowledge in familiar contexts, a process referred to as "near transfer" [3], [4] or where potential exists for recalling and using prior knowledge in new ways or in unfamiliar contexts, a process referred to as "far transfer." It is at the access points where new knowledge may be retained and linked to a learner's existing knowledge structures. The information perceived at those access points triggers the recall of prior knowledge, and it is at those points where a learner may repeat cognitive processes to gain automaticity, review and reinforce understandings, retain new knowledge or strengthen links between existing knowledge structures. It is also at those access points where new and different information may cause disjuncture and a reflective examination of one's knowledge may occur, potentially resulting in the refinement of partial conceptions, rejection of misconceptions and an opportunity to intentionally change one's mind [5], [6].

After describing the learning-well cycle, we then apply it in the framework of a relatable story that is intended to help students develop an awareness of the fact that they experience the cycle quite often, but generally are not conscious of those experiences or cognizant of ways to make them more successful. The story we use is also intended to illustrate the importance of other people's contributions at access points when they share their experiences, knowledge, ideas, questions, and stories. 
Access points may be described as existing within several well-established learning theories and models that stress the importance of interacting with other people to enable important learning. For example, in [7] situated learning theory, the access points occur within the authentic situations when a novice interacts directly or peripherally with others within a community of practice. In social construction theory, access happens in the zone of proximal development [8]. In social cognitive theory, access takes place where the actions of others in cultural and social settings are observed [8], [9]. In cooperative and collaborative learning, access occurs when learners pool their cognitive resources [10]-[17]. In problem-based or project-based learning, the access points with the greatest learning potential begin when the group members start communicating with each other [18], [19].

A through-line across each of the above theories and models is that interaction enables and/or enhances important access. Moreover, if those interactions take place in meaningfully rich contexts, then the potential for long term retention is increased. The access points our workshops primarily focus on occur when student groups are tasked with co-developing lists of the characteristics of exemplary and terrible group members. The two questions we ask students come from a contribution to an email discussion on team building by Claire Lamonica of Illinois State University (2/17/2011).

We initially ask students to reflect on their prior group work experiences to create their individual lists of group member characteristics. In other words, we ask them to access what they already know about group work. We then get them into their preassigned groups to share their lists and create group consensus lists. The objective for this activity emerged from an understanding that our students (collectively) already possess the group work knowledge it takes for groups to function well. What they often lack is confidence in the usefulness of their experientially derived knowledge or the skill to effectively access and apply it in their groups. They also lack an awareness of the powerful opportunity for learning that group work represents.

The workshop concludes with student groups sharing their group member characteristics lists with the class. This sharing always provides opportunities for us as workshop facilitators to validate and reinforce their ideas by relating them to similar concepts we have drawn from project management and learning sciences literature. We close the workshop by emphasizing that, by sharing their group work ideas and past experiences, they were proactively and in a nonconfrontational way negotiating group norms.

After the workshop, students send their group consensus lists to us, and we transfer the group lists to a peer participation assessment form (adapted from [20]). The exemplary and terrible group member characteristics become the unique assessment criteria that students will be asked to consider when assessing the participation and contributions of group members. We advise their professors to initiate the peer assessments at multiple junctures in the group project process. We suggest that the assessment process should initially be used formatively, to reinforce the importance of good group work by each member. Anecdotally, those professors have told us that the proactive norm-setting and use of the group-generated peer assessments has dramatically cut down on the group work problems that vexed them in the past. 
We have conducted our workshop in over 40 engineering project-based and capstone courses, collecting characteristics lists from over 380 unique student groups. In the following sections, we will discuss our initial analysis of some of that data, and our findings.

\section{Methods}

We limited our initial analysis to data collected in a selection of lower- and upper-division undergraduate engineering course offerings at the University of Washington. The course offerings took place between 2015 and 2018 and included multiple sub-disciplines: aeronautics $\&$ astronautics, bioengineering, industrial engineering, and design for pre-engineers. Our sample consisted of 300 group consensus characteristics of exemplary group members as collected from 44 groups. The groups ranged in size from three to nine members, with an average of 4.9 members per group. (We have not yet analyzed the characteristics of terrible group members.) On average, each group contributed 6.8 characteristics to our sample.

Using data similar to but distinct from the 300 characteristics analyzed for this paper, two researchers worked together to develop a set of 22 inductive codes for categorizing the characteristics. The iterative development process involved coding provisionally, comparing interpretations, and modifying codes for characteristics sampled for variation from data collected in the same or similar courses as those listed above. The researchers made an effort toward in vivo codes-i.e., using the participants' words when naming codes. After refining guidelines that describe the 22 codes, the two researchers were able to reach at least $80 \%$ agreement when coding independently. At this point, the researchers coded the sample of 300 characteristics described above, negotiating coding discrepancies to consensus. Note that each characteristic can be assigned multiple codes, accommodating the occasional compound characteristic that groups phrased as a single characteristic. For example, "Be respectful and open to ideas" was coded both Respectful and Group oriented. The final consensus coding of the 300 characteristics consisted of 325 code applications.

\section{Findings}

The majority of the 44 project groups identified at least one exemplary group member characteristic that matched the following four codes: Communicates, Group oriented, Works, and Responsible. Table 1 provides descriptions of each of the four codes. These descriptions are from the coding guidelines developed, revised, and used by the researchers. Additionally, Table 1 includes illustrative quotations drawn directly from the group characteristics lists. 
Table 1: Top four inductive codes for characteristics of exemplary group members, code descriptions, and illustrative example quotations.

\begin{tabular}{|l|l|l|}
\hline \multicolumn{1}{|c|}{ Code } & \multicolumn{1}{|c|}{ Code description } & \multicolumn{1}{c|}{ Illustrative quotations } \\
\hline Communicates & $\begin{array}{l}\text { Includes references to communication over } \\
\text { any medium/channel (e.g., voice, writing, } \\
\text { online), listening, giving or receiving } \\
\text { criticism, communicating expectations or } \\
\text { updates, initiating communication, } \\
\text { responding promptly, questioning, and } \\
\text { teaching. }\end{array}$ & $\begin{array}{l}\text { "Easy to get in contact with (responds } \\
\text { quickly to emails, etc)" } \\
\text { "Critical (provides feedback)" } \\
\text { "Good communicator: Essential skill } \\
\text { that allows own ideas to be clearly and } \\
\text { effectively transmitted to the rest of } \\
\text { the team." }\end{array}$ \\
\hline $\begin{array}{l}\text { Group } \\
\text { oriented }\end{array}$ & $\begin{array}{l}\text { Includes references to being flexible or } \\
\text { inclusive (e.g., open minded about ideas, } \\
\text { opinions, and decisions; risk-taking; group } \\
\text { roles; scheduling) and being aware and } \\
\text { supportive of the group or its members and } \\
\text { their respective objectives, roles, and } \\
\text { strengths. }\end{array}$ & $\begin{array}{l}\text { "Flexible and open to group members' } \\
\text { ideas" } \\
\text { "Keeps team on track and focused" }\end{array}$ \\
"Curiosity of other's point of view" \\
$\begin{array}{l}\text { Includes references to doing work } \\
\text { consistently, reliably, in a timely fashion, } \\
\text { and at a high standard; as well as doing their } \\
\text { fair share of work, managing timelines, and } \\
\text { assisting or supporting the rest of the group } \\
\text { (e.g., by taking on excess workload). }\end{array}$ & $\begin{array}{l}\text { "Responsible/Trustworthy: Staying } \\
\text { focused towards a goal and completing } \\
\text { your assigned tasks. Team member } \\
\text { does their fair share of work without } \\
\text { having to be asked or reminded to do } \\
\text { so." }\end{array}$ \\
\hline Responsible & $\begin{array}{l}\text { Includes references to being reliable (except } \\
\text { for specific references to getting work done } \\
\text { reliably, which should be coded Works, } \\
\text { instead), trustworthy, and accountable. }\end{array}$ & $\begin{array}{l}\text { "Shows up to group sessions" } \\
\text { "Dependable - Timely" } \\
\text { "Can be held accountable" }\end{array}$ \\
\hline
\end{tabular}

All but two of the 44 groups had at least one characteristic referencing communication (Table 2). In close second was Group orientation, with 38 groups including such consideration among their consensus characteristics. 28 and 25 groups' consensus characteristics referenced working and responsibility, respectively, at least once. These four codes also represented the dominant themes as measured in terms of number of matching characteristics. These codes were the only ones that matched over $10 \%$ of the characteristics, with $24 \%$ of characteristics coded Communicates, $21 \%$ coded Group oriented, $14 \%$ coded Works, and 13\% coded Responsible.

When we examined the groups' respective consensus sets of characteristics, we found that just under a third of the groups (13 of 44) had characteristics that, together, covered all four top codes. The top two codes (Communicates and Group oriented) co-occurred very frequently, with 36 of 44 groups having characteristics that covered them. Table 2 lists all of the codes and the extent to which of each was found in the group lists. 
Table 2: Inductive codes for characteristics of exemplary group members, as reported by groups of engineering undergraduates, listed in decreasing order by number of groups with one or more characteristics matching the code. Codes with matches for a majority of groups are italicized.

\begin{tabular}{|l|l|}
\hline Code & \# teams (of 44) \\
\hline communicates & 42 \\
\hline group oriented & 38 \\
\hline works & 28 \\
\hline responsible & 25 \\
\hline contributes & 19 \\
\hline positive attitude & 11 \\
\hline respectful & 11 \\
\hline organized & 9 \\
\hline engaged & 7 \\
\hline motivated & 6 \\
\hline honest & 6 \\
\hline judicious & 5 \\
\hline creative & 4 \\
\hline skillful & 4 \\
\hline available & 3 \\
\hline results oriented & 3 \\
\hline knowledgeable & 3 \\
\hline resilient & 3 \\
\hline critical thinker & 2 \\
\hline ethical & 2 \\
\hline resourceful & 2 \\
\hline trusting & 1 \\
\hline
\end{tabular}

Our first observation is that a majority of the codes are interpersonal in nature. That is, they identify a characteristic of a person that makes sense or is relevant only in the context of interpersonal activity. Consider, for instance, a more obvious example, like Respectful. Respect describes how one relates with another person. Whether an individual is respectful has little consequence outside of a group or other interpersonal situation. (Here, we assume these groups were not referring to the notion of an individual respecting one's self, as important as that is.) In contrast, characteristics such as being organized, motivated, creative, and skillful can be valuable to an individual working alone, as well as in a group context.

Among the top four codes, Communicates, Group oriented, Works, and Responsible, three are obviously interpersonal in nature; only Works appears to be the exception. However, when we examine how this code is elaborated upon in the previous section, we see that many of the ways in which groups discussed work were indeed in interpersonal terms - e.g., getting work done reliably and in a timely fashion or dividing work across the group equitably. Interpersonal characteristics feature prominently as we continue down the list in rank order: Contributes, Respectful, Engaged, and Honest.

Considering the focus of the workshop that was the context in which our group member characteristics data was collected, we hoped that the more frequently observed characteristics 
would contribute as much to learning as project completion. More generally, we also hoped that the data would reflect student focus on professional skills, rather than the traditional technical knowledge and skills that engineering curricula typically emphasize. The above findings seem to bear out both, given the dominance of Communication (42 of 44 groups, 24\% of characteristics) and Group oriented (38 of 44 groups, $21 \%$ of characteristics), as well as the finding that 36 of 44 groups' consensus lists matched both Communication and Group oriented codes.

\section{Discussion}

In this section, we examine the student groups' conceptions of good group work (and group learning) in the context of prior work. We see that their conceptions, at least in aggregate, align well with guidance from a varied sample of authorities and research. While this guidance on good group work naturally differs in wording and structure, substantial alignment with our empirical findings is evident at the conceptual level, as seen in Table 3.

\section{Marin-Garcia \& Lloret, 2007}

In their paper directed at engineering educators, Marin-Garcia and Lloret [21] drew from the management, higher education, and engineering education literatures to assemble a set of criteria instructors can use to assess group process when observing in-class student group work. Their focus on process (vs. "product") intentionally excludes assessment of the work students are doing ("what the team has to hand in"). Despite this process focus, we found substantial alignment with our Works code, probably because of our code is similarly focused on how group members work and not just the product of their work. In Table 3, we align Marin-Garcia and Lloret's criteria, clause by clause, to the top four codes we developed from student data. Only the clauses "showing a positive attitude" and "creativity" lacked substantive alignment with our four most frequently observed codes. (A quarter of the groups in our data did reference Positive attitude in their lists of characteristics, however.)

\section{Katzenbach \& Smith, 2001}

In their book, The Discipline of Teams, business and management authorities Katzenbach and Smith [22], [23] described five "basic elements" that are essential to small-group performance. As seen in Table 3, these elements align well with our top four codes. The authors distinguish between groups with and without a formal, single leader, with the latter typifying the groups that

we see in our local engineering courses. Groups that apply the "team discipline" require all group members to be involved in negotiating and holding both themselves and each other accountable to group goals and process. Our workshop approach facilitates exactly this kind of team discipline by ensuring that all group members participate in establishing and enforcing mutual expectations. 
Table 3: Top four inductive codes' alignment with conceptions of group work found in education and project management literature.

\begin{tabular}{|c|c|c|c|c|}
\hline & $\begin{array}{l}\text { Marin-Garcia \& } \\
\text { Lloret, 2007 }\end{array}$ & $\begin{array}{l}\text { Katzenback \& Smith, } \\
2001\end{array}$ & Smith \& Imbrie, 2007 & $\begin{array}{l}\text { Hirsch \& McKenna, } \\
2008\end{array}$ \\
\hline 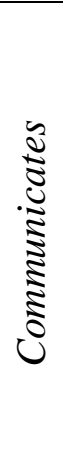 & $\begin{array}{l}\text { "appropriate } \\
\text { interpersonal } \\
\text { communication (active } \\
\text { listening, ..., positive } \\
\text { feedback)," "quality } \\
\text { of...documents } \\
\text { presented" }\end{array}$ & $\begin{array}{l}\text { (basic element } 2 \text { ) } \\
\text { "communicate and } \\
\text { coordinate effectively" }\end{array}$ & $\begin{array}{l}\text { The authors put special } \\
\text { emphasis on the } \\
\text { importance of } \\
\text { communication skills, } \\
\text { especially listening, } \\
\text { among "teamwork } \\
\text { skills." }\end{array}$ & $\begin{array}{l}\text { "Communication" was } \\
\text { the most frequently } \\
\text { observed category, with } \\
77 \% \text { of students } \\
\text { mentioning a matching } \\
\text { characteristic. } \\
\text { Components of other } \\
\text { categories also align, } \\
\text { such as "compromise," } \\
\text { under category "conflict } \\
\text { resolution" (12\%). }\end{array}$ \\
\hline $\begin{array}{c}0 \\
0 \\
0 \\
0 \\
0 \\
0 \\
0 \\
0 \\
0 \\
0 \\
0\end{array}$ & $\begin{array}{l}\text { "appreciating other } \\
\text { points of view," } \\
\text { "delegating/leading } \\
\text { without dominating," } \\
\text { "accepting and } \\
\text { assuming } \\
\text { responsibilities," } \\
\text { "suitable handling of } \\
\text { disputes," "decision- } \\
\text { making/group problem- } \\
\text { solving" }\end{array}$ & $\begin{array}{l}\text { (basic element 1) "an } \\
\text { understandable charter" } \\
\text { that articulates the } \\
\text { group's goals } \\
\text { (basic element 3) "clear } \\
\text { roles and areas of } \\
\text { responsibility," which } \\
\text { are likely to change } \\
\text { during the course of } \\
\text { group work }\end{array}$ & $\begin{array}{l}\text { Most of the other } \\
\text { "teamwork skills" they } \\
\text { identify concern making } \\
\text { decisions, solving } \\
\text { problems, and managing } \\
\text { conflicts as a team. } \\
\text { "Group accountability" } \\
\text { also aligns with this } \\
\text { code. }\end{array}$ & $\begin{array}{l}\text { Multiple categories } \\
\text { align, including "shared } \\
\text { goal" (33\%) and } \\
\text { "diversity" (e.g., of } \\
\text { group members" } \\
\text { respective strengths, } \\
37 \%) \text {, as well as } \\
\text { components of } \\
\text { "communication", such } \\
\text { as "having an open } \\
\text { mind." }\end{array}$ \\
\hline$\frac{n}{\frac{n}{2}}$ & $\begin{array}{l}\text { "amount or frequency of } \\
\text { participation in the } \\
\text { group," "quality of } \\
\text { participations in the } \\
\text { group," "preparation of } \\
\text { meetings (homework } \\
\text { done)," "gathering and } \\
\text { processing of } \\
\text { information prior to the } \\
\text { meeting," "meeting } \\
\text { deadlines" }\end{array}$ & $\begin{array}{l}\text { (basic element } 4 \text { ) "time- } \\
\text { efficient process" } \\
\text { (basic element } 3 \text { ) "clear } \\
\text { roles and areas of } \\
\text { responsibility" }\end{array}$ & $\begin{array}{l}\text { "Promotive interaction" } \\
\text { refers to group members } \\
\text { supporting each other in } \\
\text { getting work done, as } \\
\text { well as in learning. }\end{array}$ & $\begin{array}{l}\text { "Equal division of } \\
\text { work" }(65 \%) \text { was the } \\
\text { second most frequently } \\
\text { observed category. }\end{array}$ \\
\hline $\begin{array}{l}\frac{0}{0} \\
\frac{5}{2} \\
0 \\
\frac{2}{5} \\
2 \\
2\end{array}$ & $\begin{array}{l}\text { "attendance at } \\
\text { meetings," "preparation } \\
\text { of meetings (homework } \\
\text { done)," "accepting and } \\
\text { assuming } \\
\text { responsibilities" }\end{array}$ & $\begin{array}{l}\text { (basic element 5) "a } \\
\text { sense of accountability" } \\
\text { (basic element 4) "time- } \\
\text { efficient process" }\end{array}$ & $\begin{array}{l}\text { "Individual and group } \\
\text { accountability" } \\
\text { primarily aligns with } \\
\text { this code but also with } \\
\text { Group oriented. }\end{array}$ & $\begin{array}{l}\text { Category "trust" (31\%) } \\
\text { aligns directly, as well } \\
\text { as "doing their part," a } \\
\text { component of "equal } \\
\text { division of work." }\end{array}$ \\
\hline
\end{tabular}

\section{Smith \& Imbrie, 2007}

In their engineering textbook, Teamwork and Project Management, Smith and Imbrie [24] note that both education and workplace research indicate five characteristics of effective teams: positive interdependence, individual and group accountability, promotive interaction, teamwork skills, and group processing. In light of Smith's extensive prior work on cooperative learning [10], [11], [15], [17], it is no surprise that these characteristics mirror the essential elements of 
cooperative learning. Given our interest in helping students recognize and leverage the unique learning opportunities in group work, we were gratified to find substantial alignment (as seen in Table 3) between the Smith and Imbrie characteristics and our top four codes.

Hirsch \& McKenna, 2008

To compare our empirical observations with other studies of engineering students, we look to Hirsch and McKenna's work with first-year undergraduate engineering students enrolled in a required course on teamwork, communication, and project work in design [25]. The authors analyzed student responses to a prompt for "factors that contribute to successful team performance," collected at the start and end of the required course. Our data is more analogous to their start-of-course data, since we collected data in workshops that happened early in the duration of a group project. Accordingly, in Table 3, we compare our top four codes to the categories of factors that Hirsch and McKenna most frequently observed in their start-of-course data. Hirsch and McKenna, like us, found that "students could thoughtfully discuss a wide range of teamwork essentials." We note that the authors collected individual data, in contrast to our per-group data. We found no reason to expect this difference in method to threaten the validity of qualitative comparisons of aggregate data, as we do here.

\section{Implications}

The findings discussed above, support our assumption that the majority of students in American colleges come to college with a wealth of previous experiences in groups. Those experiences equate to practical personal heuristics regarding what an effective group member should know and do. Our research demonstrates that students' notions of group work correlate well with models and conceptions of group work found in both the learning sciences and project management literature. Moreover, our research indicates that students' expectations for their group members are focused mainly on interpersonal (professional) skills and knowledge and appear to deemphasize technical skills and knowledge. The types of expertise students want embodied in their group members relate to clear and timely communication, positive attitudes toward and consideration of their group members, and an ability to carry through on mutually agreed to tasks.

When students are asked to reflect on their past group work experiences, it appears they understand well that a lack of strong interpersonal skills diminishes the potential of groups far more often than does a dearth of technical skill. These findings suggest several implications for engineering education: Our students' prior knowledge should be leveraged more effectively, and we should do a better job focusing on developing students' professional skills, including their ability to be self-regulated and metacognitive learners.

Our group work workshops were developed to support engineering educators and their students. As instructional consultants, we have worked with faculty members who struggle to keep their student project groups functioning well enough to produce successful outcomes. Often those outcomes take the form of project reports and project presentations, to which grades are assigned and shared by group members. The guiding assumption is that project outcomes are a reasonable proxy measure of individual learning. That may or may not be the case, but what seems to be an 
unfortunate result of that approach is that students efforts become fixed on project success rather than learning success.

Accepting that an important outcome of an engineering education is to prepare students for professional group work, should not compromise the quality of the education that each individual student receives. The assumption that project success equates to learning success is communicated so often to engineering students through group role-playing schemes, project process charts, task assignments, and grading plans, that students themselves will undercut their own learning for the benefit of project success. Students should learn how to divide project tasks to more effectively and efficiently work in project groups, but they should also learn how to efficiently share the knowledge they build while accomplishing individual tasks. A focus on learning outcomes helps ensure that the benefits of the diversity we build into our groups is apparent to all group members. When students understand that their group's success depends on the learning success of every group member, then the products and reports and presentations created by groups will truly be metrics of learning.

The design of our workshop rests on an abundance of research that shows there are no more powerful conditions for learning than when learners are engaged in learning with others [12], [26]. We posit that there are, also no better circumstances for learning how to learn than when students experience group work. However, what is learned and who learns it, depends (to a large extent) on what is understood by the instructor and the students to be the real point of the group work enterprise. By helping students to reveal to each other their powerful conceptual understandings of effective group work, build and validate socially shared understandings within their groups, and provide a way to implement those understandings, we not only build stronger group members but we can build stronger learners. The group member characteristics identified by engineering students in our workshops emphasize and define the kinds of personal interactions necessary to create the conditions for effective group work and learning well.

\section{References}

[1] Davis, D., Trevisan, M., Leiffer, P., McCormack, J., Beyerlein, S., Kahn, M. J., and Brackin, P. (2013). Reflection and metacognition in engineering practice. in M. Kaplan, N. Silver, D. Lavaque-Manty and D. Meizlish (Eds.) Using reflection and metacognition to improve student learning. (pp.78-103). Sterling, VA: Stylus.

[2] Nilson, L. B. (2013). Creating self-regulated learners. Sterling, VA: Stylus.

[3] Sousa, D. A. (2006). How the brain learns ( $3^{\text {rd }}$ ed.). Thousand Oaks, CA: Sage Publications.

[4] Mestre, J. (2002). Transfer of Learning: Issues and research agenda. Retrieved 1/18/2018 from https://www.nsf.gov/pubs/2003/nsf03212/nsf03212.pdf

[5] Mezirow, J. (1991). How critical reflection triggers transformative learning. In J. Mezirow \& Associates (Eds.), Fostering critical reflection in adulthood (pp. 1-20). San Francisco: Jossey-Bass. 
[6] Schein, E. H. (1964). Personal change through interpersonal relationships. In W. G. Bennis, E. H. Schein, D. E. Berlew \& F. I. Steele (Eds.), Interpersonal dynamics. Belmont, CA: Dorsey Press.

[7] Lave, J., \& Wenger, E. (1991). Situated learning: Legitimate peripheral participation. Cambridge: Cambridge University Press.

[8] Bruning, R. H., Schraw, G. J. \& Ronning, R. R. (1999). Cognitive psychology and instruction. Upper Saddle River, NJ: Prentice-Hall, Inc.

[9] Svinicki, M. D. (2004). Learning and Motivation in the Postsecondary Classroom. Boston: Anker Publishing Company.

[10] Johnson, D. W., Johnson, R. T., \& Smith, K. A. (1998). Cooperative Learning returns to college: What evidence is there that it works? Change, July/August, pp. 27-35.

[11] Johnson, D. W., Johnson, R. T., \& Smith, K. A. (1998). Active learning: Cooperation in the college classroom. Edina, MN: Interaction Book Company.

[12] Johnson, D. W., Johnson, R. T., \& Stanne, M. B. (2000). Cooperative learning methods: A meta-Analysis. Downloaded 7/11/2001 from http://www.clcrc.com/pages/cl-methods.html

[13] Millis, B., J, and Cottell Jr., P., G. (1998). Cooperative Learning for Higher Education Faculty. Westport CT: Oryx Press.

[14] Bruffee, K. A. (1999). Collaborative learning: Higher education, interdependence, and the authority of knowledge. Baltimore: Johns Hopkins University.

[15] Smith, K. A. (2000). Going deeper: Formal small-group learning in large classes. New Directions for Teaching and Learning, 81, pp.25-46. San Francisco: Jossey-Bass.

[16] Barkley, E., Cross, K. P., and Major, C. H. (2004). Collaborative learning techniques: A practical guide to promoting learning in groups. San Francisco: Jossey-Bass.

[17] Smith, K. A., Sheppard. S. D., Johnson, D. W., \& Johnson, R. T. (2005). Pedagogies of engagement: Classroom-based practices. Journal of Engineering Education, January. pp. 115.

[18] Du, X., Graaff, E. D., \& Kolmos, A. (2009). Research on PBL Practice in Engineering Education. Boston: Sense Publishers.

[19] Duch, B. J. Groh, S. E., and Allen, D. E. (2001). The power of problem-based learning: A practical "how to" for teaching undergraduate courses in any discipline. Sterling, VA: Stylus.

[20] Fink, L. D. (2002). Creating significant learning experiences: An integrated approach to designing college courses. San Francisco: Jossey-Bass.

[21] Marin-Garcia, J. A., \& Lloret, J. (2008). Improving teamwork with university engineering students. The effect of an assessment method to prevent shirking. WSEAS Transactions on Advances in Engineering Education, 5(1), 1-11. 
[22] Katzenbach, J. R. and Smith, D.K. (1993), The Wisdom of Teams: Creating the Highperformance Organisation, Harvard Business School, Boston.

[23] Katzenbach, J. R. and Smith, D. K. (2001). The Discipline of Teams. New York: John Wiley \& Sons, Inc.

[24] Smith, K. A., \& Imbrie, P. K. (2007). Teamwork and Project Management (McGraw-Hill's Best-Basic Engineering Series and Tools). McGraw-Hill Science/Engineering/Math.

[25] Hirsch, P. L., \& McKenna, A. F. (2008). Using reflections to promote teamwork understanding in engineering design education. International Journal of Engineering Education, 22(2), 377-385.

[26] Hake, R. (1998). Interactive engagement vs. traditional methods: A six-thousand student survey of mechanics test data for introductory physics courses. American Journal of Physics, 66 (1) pp. 64-74. 